\title{
GMR
}

\section{Estimation of genetic variability among peanut genotypes for resistance to leaf spot disease}

\author{
Q. Bano', M. Hassan'1, S.B. Hussain'2, M. Javed², M.A. Zulfiqar³, \\ M. Younas ${ }^{4}$, M. Baber ${ }^{5}$, M. Zubair ${ }^{6}$ and S.M. Hussain ${ }^{7}$ \\ ${ }^{1}$ Department of Plant Breeding and Genetics, PMAS Arid Agriculture University, \\ Rawalpindi, Pakistan \\ ${ }^{2}$ Department of Plant Breeding \& Genetics, \\ Faculty of Agricultural Sciences \& Technology, Bahauddin Zakariya University, \\ Multan, Pakistan \\ ${ }^{3}$ PARC, Research and Training Station, Bahauddin Zakariya University, \\ Multan, Pakistan \\ ${ }^{4}$ Department of Plant Breeding \& Genetics, University of Agriculture, \\ Faisalabad, Pakistan \\ ${ }^{5}$ Institute of Molecular Biology \& Biotechnology, Bahauddin Zakariya University, \\ Multan, Pakistan \\ ${ }^{6}$ Department of Forestry \& Range Management, FAS\&T, \\ Bahauddin Zakariya University, Multan, Pakistan \\ ${ }^{7} \mathrm{NARC}$, Isalmabad, Pakistan \\ Corresponding author: S.B. Hussain \\ E-mail: drsyedbilal@hotmail.com
}

Genet. Mol. Res. 15 (3): gmr.15038213

Received December 7, 2015

Accepted February 11, 2016

Published August 12, 2016

DOI http://dx.doi.org/10.4238/gmr.15038213

Copyright (C 2016 The Authors. This is an open-access article distributed under the terms of the Creative Commons Attribution ShareAlike (CC BY-SA) 4.0 License.

ABSTRACT. This study aimed to identify high-yielding peanut genotypes with resistance to leaf spot disease. The experiments 
included material from fourteen local and four exotic peanut genotypes that showed highly significant differences among morphological and disease severity parameters in all the genotypes which, in turn, suggested diversity genotypes. Disease severity analysis showed that the highest disease score and damaged leaf area were observed in the genotype Kelincer and the lowest scores and leaf damaged areas were observed in Majalaya super and BARI-2000, respectively. Based on these results, the genotypes BARI-2011, Chakori, Golden, BARI-89, Majalaya Super, BARD-699, BARI-2000, SP-1, and No. 334 can be used by breeders in peanut improvement programs for the development of new cultivars with higher disease resistance and increased yield.

Key words: Genetic variability; Peanut; Resistance; Leaf spot

\section{INTRODUCTION}

Peanut (Arachis hypogaea L.) belongs to the family Fabaceae and is widely cultivated for its edible seeds and high forage value for livestock. This plant is also known as groundnut or monkey nut (Acquaah, 2007). The crop is genetically drought tolerant and can reach maturity without any irrigation. It is cultivated worldwide on an area of 23.28 million ha, with a production of 39.93 million metric tons and an average yield of $1720 \mathrm{~kg} / \mathrm{ha}$. China leads the world producing 16.70 million metric tons of peanuts on an area of 4.70 million ha (USDA, 2013). In Pakistan, this leguminous oil seed crop is cultivated in an area of approximately 81.5 thousand ha, with a production of 91.4 thousand tons, $85 \%$ of which is contributed by the Pothohar regions of Punjab, 12\% by KPK (Khyber Pakhtonkhwa), and 3\% by Sindh, Pakistan (Anonymous, 2013). In Pakistan, the average pod yield of peanut was recorded as $1100 \mathrm{~kg} / \mathrm{ha}$, which was considered very low compared to developed countries producing 2500 $\mathrm{kg} / \mathrm{ha}$. The constraints in peanut productivity mainly include a narrow genetic base due to its susceptibility to various biotic and abiotic stresses. Among biotic stresses, fungal diseases cause the most plant damage. Early and late leaf spot caused by Cercospora arachidicola and Cercosporidium personatum are the most common and serious diseases of peanut worldwide. Individually or together they cause losses of approximately $50 \%$ in pod yield; in areas where rust disease occurs; a combined attack of foliar diseases cause losses up to $70 \%$ in yield (Anonymous, 2013). Although CLS can also be controlled with the use of appropriate fungicides, their use is expensive and not readily available to small-scale farmers (Hossain et al., 2007). The development of disease-resistant cultivars is a robust, cost effective, and environment friendly solution among all the disease management approaches. In addition, disease-free forage of high nutritional value would impact livestock feeding. Therefore, it is useful to identify sources of resistance for the development of disease-resistant varieties of peanut.

The present study aimed to evaluate the genetic diversity of disease and yield-related parameters in peanut germplasm and identify leaf spot-resistant, high-yielding genotypes to be used in subsequent breeding programs.

\section{MATERIAL AND METHODS}

The experiment was conducted in the Department of Plant Breeding and Genetics,

Genetics and Molecular Research 15 (3): gmr.15038213 
at PMAS-Arid Agriculture University, Rawalpindi, during 2013-2014, which is located at $33.6058 \mathrm{~N}$ and $73.0437 \mathrm{E}$ of latitude and longitude, respectively. The experiment was conducted using a completely randomized design with five experimental replicates. Eighteen genotypes were grown in sandy loam soils with $45 \mathrm{~cm}$ row spacing and $10 \mathrm{~cm}$ plant to plant spacing. One month after sowing, the plants were inoculated with $C$. arachidicola and Phaeoisariopsis personata. Data on the number of pods per plant, number of seeds per pod, biological yield, pod yield, seed yield, leaf area, number of days to the appearance of 1st leaf spot after inoculation, number of spots per leaf, and leaf spot area were recorded. The data were subjected to simple analysis of variance technique of Steel et al. (1997) to observe whether the research material differences for plant traits are significant.

\section{RESULTS AND DISCUSSION}

\section{Number of pods per plant}

Increased number of pods per plant contributes towards increased yield in peanut varieties. Analysis of variance for the number of pods per plant showed highly significant differences among all the genotypes (Table 1). The genotype Majalaya Super demonstrated the maximum pods per plant (15.4), followed by SP-1 (14.6), Golden (13.6), Chakori (13.5), and BARD-699 (13.4). The minimum number of pods was observed in genotypes Kelincer, Majalaya, No. 334, and BARI-89, which showed statistically similar results (5.2).

These results contrast with the findings of Naeem-ud-Din et al. (2012) in the case of BARI-2011.

Table 1. Analysis of variance for number of pods per plant.

\begin{tabular}{l|c|c|c|c|c}
\hline No. of pods & Sum of squares & d.f. & Mean square & F-statistics & P value \\
\hline Between groups & 575.764 & 17 & 33.868 & 13.578 & 0.000 \\
\hline Within groups & 174.6 & 70 & 2.494 & & \\
\hline Total & 750.364 & 87 & & & \\
\hline
\end{tabular}

Grand mean $=11.13 ; \mathrm{CV}=14.16 \%$.

\section{Number of seeds per pod}

Analysis of variance for number of seeds per pod showed highly significant difference between genotypes (Table 2). The maximum (30.2) seeds per pod were found in genotype BARI-2011 followed by Majalaya Super (26), SP-1 (25.5), No. 334 (25), Chakori (23.5), and BARI-2000 (23). The minimum number of seeds was recorded in genotypes Kelincer (9), 96CG005 (12.8), and 11CG005 (13.2). The increased number of seeds per pod may be a result of disease resistance or other morphological traits in BARI-2011 and the other respective genotypes with greater numbers of seeds per pod.

These results are consistent with the findings of Naeem-ud-Din et al. (2012), who found that BARI-2011 has more seeds per pod as well as being a better plant type when compared to No. 334, Chakori, BARI-2000, Golden, and BARD-479. They also observed resistance against root rot and Cercospora leaf spot in BARI-2011.

Genetics and Molecular Research 15 (3): gmr.15038213 
Table 2. Analysis of variance for number of seeds per pod.

\begin{tabular}{l|c|c|c|c|c}
\hline No of seeds & Sum of squares & d.f. & Mean square & F-statistics & P value \\
\hline Between groups & 2403.791 & 17 & 141.399 & 31.95 & 0.000 \\
\hline Within groups & 309.8 & 70 & 4.426 & & \\
\hline Total & 2713.591 & 87 & & & \\
\hline
\end{tabular}

Grand mean $=20.06 ; \mathrm{CV}=10.47 \%$.

\section{Biological yield per plant}

Analysis of variance showed that there is a significant difference among the selected genotypes for biological yield per plant as shown in Table 3. The maximum biological yields were observed in the genotypes Golden (36.2 g), BARI-89 (33.6 g), Chakori (31.5 g), and No. 334 (29.4 g). Majalaya Super and BARI-2011 had the same biological yield (27.2 g), while the biological yield per plant minimums were recorded for 11CG005 (12.2 g), Kelincer (12.2 g), 96CG005 (14.2 g), Bard-479 (15.2 g), and Majalaya (16.2 g), respectively.

These results are consistent with the findings of Saeed and Hassan (2009), who obtained an average biological yield of $2815 \mathrm{~kg} / \mathrm{ha}$ for genotype Golden, while that for BARI2000, BARD-479, and No. 334 were 2258, 2398, and $2146 \mathrm{~kg} / \mathrm{ha}$, respectively.

Table 3. Analysis of variance for biological yield per plant (grams).

\begin{tabular}{l|c|c|c|c|c}
\hline Biological yield & Sum of squares & d.f. & Mean square & F-statistics & P value \\
\hline Between groups & 4413.33 & 17 & 259.608 & 22.332 & 0.000 \\
\hline Within groups & 813.75 & 70 & 11.625 & & \\
\hline Total & 5227.08 & 87 & & & \\
\hline
\end{tabular}

Grand mean $=22.60 ; \mathrm{CV}=15.08 \%$.

\section{Pod yield per plant}

Analysis of variance of yield showed highly significant differences between all the genotypes (Table 4). Chakori and BARI-2011 have maximum pod yields of 13.5 and $12.4 \mathrm{~g}$, respectively; where as the lowest yielding genotypes were 11CG005 (4 g), Bard-479 (4.8 g), and Kelincer (5 g).

Table 4. Analysis of variance for pod yield per plant (grams).

\begin{tabular}{l|c|c|c|c|c}
\hline Pod yield & Sum of squares & d.f. & Mean square & F-statistics & P value \\
\hline Between groups & 548.773 & 17 & 32.281 & 34.433 & 0.000 \\
\hline Within groups & 63.75 & 68 & 0.938 & & \\
\hline Total & 612.523 & 85 & & & \\
\hline
\end{tabular}

Grand mean $=8.31 ; \mathrm{CV}=11.59 \%$.

\section{Seed yield per plant}

The analysis of variance for seed yield per plant showed highly significant differences among all the genotypes (Table 5). The maximum seed yield per plant was observed in 
genotype BARI-2011 (6.858 g), which forms a homogeneous group with Chakori (6.365 g), Golden (6.322 g), BARD-699 (5.992 g), and Majalaya Super (5.864 g). The minimum seed yields were observed in Kelincer (1.344 g) and BARD-479 (2.096 g).

Table 5. Analysis of variance for seed yield per plant (grams).

\begin{tabular}{l|c|c|c|c|c}
\hline Seed yield & Sum of squares & d.f. & Mean square & F-statistics & P value \\
\hline Between groups & 201.094 & 17 & 11.829 & 20.301 & 0.000 \\
\hline Within groups & 40.787 & 70 & 0.583 & & \\
\hline Total & 241.882 & 87 & & & \\
\hline
\end{tabular}

Grand mean $=4.31 ; \mathrm{CV}=17.64 \%$.

\section{Disease scoring for fungal pathogen resistance}

Scoring of disease was based on visually observing disease severity on a 9-point scale, where 0 is for no disease or no visual symptoms of disease incidence, and 9 is for complete defoliation of the plant. Variation in the development and severity of disease among different genotypes can be scored at different times during the entire cropping period.

Analysis of variance showed that there is a significant difference among genotypes of peanut in the severity of leaf spot disease (Table 6). The maximum scores were observed in genotypes Kelincer (8.6), 11CG005 (8.2), and 02CG002 (7.2). These data suggest that these genotypes are highly susceptible to leaf spot disease. In contrast, the minimum scores were measured in the genotypes Majalaya Super (2.3) and BARI-2000 (3). The genotypes BARD699 (3.4), Golden (3.6), BARI-2011 (3.8), No. 334 (3.8), and BARI-89 (4) also had reasonable scores and can be considered as moderately resistant genotypes of peanut.

Table 6. Analysis of variance for scoring of leaf spot disease on a scale of 1-9.
\begin{tabular}{|l|c|c|c|c|c}
\hline Scoring & Sum of squares & d.f. & Mean square & F-statistics & P value \\
\hline Between groups & 290.773 & 17 & 17.104 & 29.26 & 0.000 \\
\hline Within groups & 39.75 & 68 & 0.585 & & \\
\hline Total & 330.523 & 85 & & & \\
\hline
\end{tabular}

Grand mean $=5.31 ; \mathrm{CV}=14.39 \%$.

\section{Percentage of damaged leaf area by fungal infection}

Damaged leaf area is a key parameter used to estimate the infected area of the leaf and has a direct relationship with disease severity, as the diameter of spots and damaged area are both influenced by environment and plant genotype. Analysis of variance showed that there was a significant difference among the genotypes in terms of damaged leaf area after fungal infection (Table 7). The maximum leaf damage was observed in Kelincer (36.12\%), BARD$479(23.031 \%), 02 \mathrm{CG} 002(13.286 \%)$, and 10CG003 (11.7875\%). These varieties may be more susceptible to leaf spot disease than the other genotypes tested. The genotypes that had the minimum mean of damaged leaf area were BARI-2000 (3.508\%), SP-1 (4.1), Majalaya Super (4.865\%), Golden (5.292\%), and Bari-2011 (5.425). These genotypes reflect a better tolerance to leaf spot disease compared to the genotypes with greater damaged leaf areas.

Genetics and Molecular Research 15 (3): gmr.15038213 


\section{Table 7. Analysis of variance for the percent of damaged leaf area.}

\begin{tabular}{l|c|c|c|c|c}
\hline Biological yield & Sum of squares & d.f. & Mean square & F-statistics & P value \\
\hline Between groups & 5185.71 & 17 & 305.042 & 273 & 0.000 \\
\hline Within groups & 75.91 & 68 & 1.116 & & \\
\hline Total & 5261.62 & 85 & & & \\
\hline
\end{tabular}

Grand mean $=10.832 ; \mathrm{CV}=9.75 \%$.

\section{DISCUSSION}

Based on correlation between morphological and disease severity parameters studied in peanut genotypes for resistance to Cercospora leaf spot disease, it can be suggested that genotypes BARI-2011, BARI-2000, BARI-89, Golden, Chakori, Majalaya Super, and SP-1 showed better results in field conditions against Cercospora leaf spot disease in terms of better biological yield and lowest score and leaf damaged area with no limitations. These selected genotypes can be expected to show better performance in disease infected areas of Pakistan and to be used by the breeders in peanut improvement programmes, which would help in developing new cultivars with higher disease resistance and increased yield.

\section{Conflicts of interest}

The authors declare no conflict of interest.

\section{ACKNOWLEDGMENTS}

The authors acknowledge the technical services provided by the laboratory staff of the Department of Plant Breeding \& Genetics, Bahauddin Zakariya University, Multan, Pakistan.

\section{REFERENCES}

Acquaah G (2007). Principles of plant genetics and breeding. Blackwell Pub. Ltd., Malden, USA: 1235-1255.

Anonymous (2013). Pakistan Agriculture Research Council.

Hossain MD, Rehman MZ, Abeda K and Rahman MM (2007). Screening of groundnut genotypes for leaf spots and rust resistance. Int. J. Sustain. Crop Prod 2: 7-10.

Naeem-ud-Din MT, Naeem MK, Hassan MF, Rabbani G, et al. (2012). Development of BARI-2011: A high yielding drought tolerant variety of Groundnut (Arachis hypogaea L.) with 3-4 seeded pods. Int. J. Animal Plant Sci. 22: $120-125$.

Saeed IQ and Hassan MF (2009). High yielding groundnut (Arachis hypogea L.) Variety "Golden". Pak. J. Bot. 41: 22172222.

Steel RGD, Torrie JH and Dicky DA (1997). Principles and procedures of statistics, a biological approach. McGraw Hill, Inc., New York.

USDA (2013). United States Department of Agriculture. Washington. 